\title{
PENGARUH LAMA PERENDAMAN RIMPANG DALAM LARUTAN PGPR TERHADAP PERTUMBUHAN BIBIT TANAMAN KENCUR (Kaempferia galanga L.)
}

\author{
Hafiz Fadillah ${ }^{1 *}$ dan Nahda Kanara ${ }^{2}$ \\ ${ }^{1}$ Mahasiswa Program Studi Budi Daya Tanaman Hortikultura, Politeknik Pertanian Negeri Payakumbuh \\ ${ }^{2}$ Dosen Program Studi Budi Daya Tanaman Hortikultura, Politeknik Pertanian Negeri Payakumbuh \\ *Email: hfadillah2262gmail.com
}

\begin{abstract}
ABSTRAK
Kencur (Kaempferia galanga L.) merupakan tanaman herbal yang memiliki banyak khasiat sebagai obat yang tumbuh didaerah tropis dan subtropis. Secara empirik kencur digunakan sebagai penambah nafsu makan, infeksi bakteri, obat batuk, disentri, tonikum, ekspektoran, masuk angin, dan sakit perut. Banyaknya manfaat kencur memungkinkan pengembangan budidayanya secara intensif yang disesuaikan dengan produk akhir yang digunakan. Perbanyakan tanaman kencur harus memperhatikan proses pembibitan seperti menggunakan rimpang tanaman tersebut. Untuk mempercepat proses pembibitan tanaman kencur dengan menggunakan rimpang, penggunakan zat pemacu/perangsang tumbuh dan juga pengendalian patogen diperlukan sehingga, dapat memaksimalkan pertumbuhan. Zat Pengatur Tumbuh (ZPT) dan pengendalian hayati dapat diperoleh pada Plant Growth Promotong Rhizobacteria $(P G P R)$ yang merupakan bakteri yang berperan penting dalam meningkatkan pertumbuhan tanaman, hasil panen, dan kesuburan lahan. Tujuan dari percobaan ini adalah untuk mengetahui pengaruh pertumbuhan tunas rimpang kencur dan untuk mengetahui lama perendaman rimpang kencur dalam larutan PGPR yang paling optimal. Percobaan ini telah dilaksanakan pada bulan Maret - April 2021. Bertempat di LPHP dan PAH Induk Bandar Buat, Padang. Percobaan ini terdiri dari beberapa perlakuan yaitu kontrol, 15 menit perendaman, 30 menit perendaman, 45 menit perendaman, dan 60 menit perendaman. Hasil percobaan menunjukkan bahwa perendaman rimpang kencur dengan PGPR berpengaruh terhadap tinggi tanaman, jumlah tunas dan berat akhir tanaman. Pertumbuhan tanaman kencur yang terbaik diperoleh pada perlakuan 45 menit perendaman dengan rata-rata tinggi tanaman 1,74 cm, jumlah tunas 1,8 buah, berat akhir 5,9 g dan jumlah rimpang yang hidup $100 \%$.
\end{abstract}

\section{Kata kunci : PGPR, kencur, bibit, lama perendaman, rimpang}

\section{PENDAHULUAN}

Tanaman herbal kini lebih sering digunakan karena memiliki nilai ekonomis yang baik serta banyak tumbuh di daerah tropis termasuk di Indonesia. Kencur (Kaempferia galanga L.) merupakan salah satu tanaman herbal yang memiliki banyak khasiat. Tanaman kencur telah banyak dimanfaatkan di kalangan industri maupun rumah tangga bukan hanya untuk obat namun dapat digunakan sebagai bahan makanan dan minuman yang kaya akan manfaat bagi kesehatan, industri kosmetika, serta bahan campuran saus rokok pada industri rokok kretek. Secara empirik kencur digunakan sebagai penambah nafsu makan, infeksi bakteri, obat batuk, disentri, tonikum, ekspektoran, masuk angin, dan sakit perut. Banyaknya manfaat kencur memungkinkan pengembangan budidayanya secara intensif yang disesuaikan dengan produk akhir yang digunakan.

Kencur memiliki tingkat permintaan yang tinggi di pasaran terutama dari pabrik obat-obatan sehingga mendorong petani untuk dapat menyediakan kencur dalam jumlah yang banyak. Budidaya tanaman kencur yang selama ini dilakukan dengan menggunakan rimpang. Menurut Rahman dkk (2005) dalam Samanhudi $d k k$ (2016), penggunaan rimpang sebagai benih pada budidaya kencur memiliki kekurangan seperti rentan terhadap hama dan penyakit, serta produktivitas yang tidak stabil.

Perbanyakan kencur menggunakan rimpang selain mempunyai potensi terserang penyakit juga memiliki kekurangan lain yaitu periode dormansi yang cukup panjang. Oleh karena itu, kencur membutuhkan pengendalian hayati dan Zat Pengatur Tumbuh (ZPT) serta kesuburan tanah agar dapat memperoleh pertumbuhan yang tepat. Menurut Lestari (2011), ZPT berperan penting dalam mengontrol proses biologi dalam jaringan tanaman. Perannya antara lain mengatur kecepatan pertumbuhan dari masing-masing jaringan dan mengintegrasikan bagian-bagian tersebut guna menghasilkan bentuk yang dikenal tanaman. Selain ZPT, rimpang yang 
tumbuh memerlukan unsur hara yang baik agar pertumbuhan maksimal.

Pengendalian hayati dan Zat Pengatur Tumbuh (ZPT) serta penyedia unsur hara dapat diperoleh pada penggunaan Plant Growth Promotong Rhizobacteria (PGPR). PGPR merupakan bakteri pemacu pertumbuhan tanaman yang berkoloni dengan perakaran dan mendukung kekebalan, pertumbuhan dan perkembangan tanaman dengan kemampuannya dalam menghasilkan ZPT. Selain itu, PGPR juga menjadi biokatalis untuk mendukung tersedianya unsur hara dan asam-asam organik penting yang dibutuhkan bagi tanaman. PGPR dapat diperoleh dengan sederhana yaitu menggunakan bahanbahan yang murah dan mudah didapatkan di sekitar lingkungan seperti akar bambu, akar rumput gajah dan akar putri malu. Dengan kegunaan PGPR sebagai ZPT, penyedia unsur hara dan pengendalian hayati dapat meningkatkan pertumbuhan dan perkembangan rimpang kencur.

Tujuan dari percobaan ini adalah:

1. Mengetahui pengaruh lama perendaman dalam larutan PGPR terhadap kualitas pertumbuhan tunas rimpang kencur

2. Mengetahui lama perendaman rimpang kencur dalam larutan PGPR yang paling optimal.

\section{METODE PENELITIAN}

\section{A. Waktu dan Tempat}

Percobaan telah dilaksanakan selama 1 bulan yang berlangsung dari bulan Maret - April 2021. Percobaan tugas akhir ini dilakukan di LPHP dan PAH Induk Bandar Buat, Kecamatan Lubuk Kilangan, Kota Padang.

\section{B. Alat dan Bahan}

Alat yang digunakan cangkul, gerobak, parang, erlemeyer, gelas piala, dandang, ember, seedbag, gunting, saringan, jirigen, corong, selang bening kecil, sendok, mesin aerator dan alat tulis. Bahan yang digunakan ialah air, akar rumput gajah, gula pasir, plastik, karet gelang, bubuk PK (Permanganas Kalium), terasi, penyedap rasa, dedak halus, injet (kapur halus), tanah, polybag, gembor, kertas label, media natrium agar (NA) dan rimpang kencur.

\section{Metode Pelaksanaan}

Perlakuan percobaan terdiri atas lima perlakuan yaitu : (1) Kontrol, (2) perendaman rimpang dengan larutan PGPR selama 15 menit, (3) perendaman rimpang dengan larutan PGPR selama 30 menit, (4) perendaman rimpang dengan larutan PGPR selama 45 menit dan (5) perendaman rimpang dengan larutan PGPR selama 60 menit.

Tahapan pelaksanaan kegiatan yang dilakukan adalah :

\section{Pembuatan PGPR}

Proses pembuatan PGPR dilakukan selama 10 hari sebelum pembuatan media tanam. Proses pembuatan PGPR yang dilakukan diawali dengan pengambilan inang dengan merendam 100 gr akar rumput gajah dalam 1 liter air yang sudah dididihkan. Rendaman lalu didiamkan selama 4 hari untuk mengembang biakkan bakteri.

Setelah didiamkan selama 4 hari, pembuatan media bakteri dilakukan dengan mencampur 400 gr gula pasir, 200 gr terasi, 100 gr dedak halus, 10 gr penyedap rasa dan $1 \mathrm{sdt}$ injet (kapur halus) ke dalam 10 liter air kemudian dididihkan. Setelah mendidih api dikecilkan dan dibiarkan selam 15 menit, api dimatikan dan tunggu hingga larutan media dingin. Setelah itu, media bakteri langsung disaring dan dimasukkan ke dalam jirigen 10 liter. Kemudian dimasukkan larutan inang bakteri sebanyak 1 liter ke dalam media bakteri. Setelah itu pemasangan instalasi sirkulasi udara pada jirigen (Gambar 1).

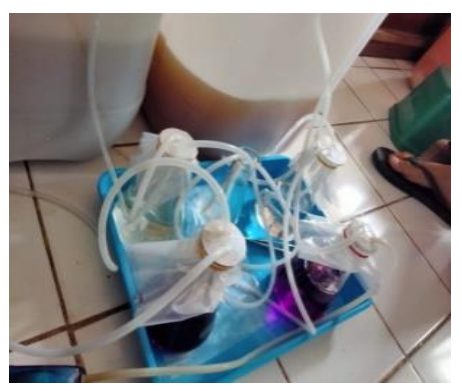

\section{Gambar 1. Instalasi Udara PGPR}

Instalasi udara pada pembiakan PGPR bertujuan untuk memberikan udara yang steril agar bakteri hidup dan berkembang serta menjaga PGPR agar tidak terkontaminasi. Terlihat pada gambar 1 udara bebas yang disalurkan pada PGPR mengalami beberapa tahapan. Tahap pertama yaitu udara bebas diambil menggunakan aerator kemudian dialirkan ke saluran udara. Kemudian udara yang dialirkan masuk kedalam larutan PK (Permanganas kalium) yang berfungsi untuk mensterilkan udara agar tidak adanya 
mikroorganisme yang masuk kedalam PGPR agar tidak terjadinya kontaminasi. Kemudian, udara yang sudah disterilkan disalurkan ke dalam jirigen PGPR. Kemudian, udara yang terdapat didalam jirigen PGPR disalurkan ke dalam wadah yang berisikan air yang bertujuan untuk menjaga sirkulasi udara tetap steril. Kemudian udara yang terdapat di dalam wadah yang berisikan air dilepaskan ke udara bebas. Pembiakan PGPR pada penggunaan instalasi udara dilakukan selama 7 hari.

Setelah pembiakan PGPR pada instalasi tersebut, pengamatan terhadap pertumbuhan koloni bakteri PGPR untuk mengetahui keberhasilan pembiakan. Pengamatan pertumbuhan koloni bakteri PGPR dilakukan dengan pengenceran larutan hingga 10 kali pengenceran kemudian larutan tersebut diletakkan pada media natrium agar (NA) yang kemudian didiamkan selama 1 hari untuk melihat koloni bakteri tersebut. Minimal jumlah bakteri pada PGPR yaitu $10^{8} \mathrm{CFU}$ (Colony Forming Unit). Jika standar jumlah tersebut telah tercapai, maka pembiakan PGPR behasil dan siap untuk digunakan.

\section{Pembuatan Media Tanam}

Pembuatan media tanam dilakukan 1 minggu sebelum penanaman. Media tanam yang digunakan yaitu tanah dan pupuk kandang sapi dengan perbandingan $1: 1$. Tanah dan pupuk kandang sapi diaduk rata dengan menggunakan cangkul hingga homogen. Setelah 1 minggu didiamkan, media tanam dimasukkan ke dalam polybag yang berukuran $10 \mathrm{~cm} \times 15 \mathrm{~cm}$ dengan mengisi media tanam $3 / 4$ polybag. Sebanyak 25 polybag dipersiapkan untuk 5 perlakuan.

\section{Pengadaan Bibit}

Pengadaan bibit dilakukan sebelum pananaman dengan memilih rimpang yang sehat dan segar. Rimpang yang dijadikan bibit sebelumnya dibersihkan dari sisa-sisa tanah. Rimpang yang dijadikan sebagai bibit memiliki bobot seberat 5 gr dan setiap rimpang memiliki 3 mata tunas yang belum aktif.

\section{Pengaplikasian PGPR}

Pengaplikasian PGPR terhadap rimpang kencur dengan cara perendaman. Larutan PGPR dibuat dengan konsentrasi $100 \mathrm{ml}$ per liter air. Rimpang kencur dimasukkan ke dalam larutan PGPR hingga terendam dengan lama perendaman sesuai dengan perlakuan yaitu perendaman selama 15 menit, 30 menit, 45 menit dan 60 menit.

\section{Penanaman}

Penanaman dilakukan seminggu setelah pembuatan media tanam. Penanaman dilakukan dengan cara membuat lubang tanam sedalam 2 $\mathrm{cm}$. Kemudian rimpang dimasukkan dalam lubang tanam yang telah disiapkan. Lubang tanam ditutup dengan tanah yang gembur dan disiram menggunakan air. Lalu polybag diletakkan di tempat yang ternaungi selama 1 minggu dan pada 2-5 minggu selanjutnya diletakkan di tempat yang tidak ternaungi.

\section{Pemeliharaan}

Pemeliharaan terdiri atas penyiraman dan penyiangan. Penyiraman dilakukan 3 hari sekali menggunakan gembor sampai media tanam dalam kondisi kapasitas lapang. Waktu penyiraman dilakukan pada pagi atau sore hari. Tujuan penyiraman adalah untuk menjaga kelembaban dan tanaman tidak mengalami kekeringan serta membantu dalam penyerapan unsur hara.

Penyiangan dilakukan dengan manual dengan mencabut gulma yang tumbuh di dalam polybag menggunakan tangan. Penyiangan dilakukan 2 minggu sekali. Tujuan penyiangan adalah agar tanaman dan gulma tidak bersaing dalam memperebutkan unsur hara, air dan sinar matahari.
Parameter Pengamatan Pertumbuhan
a. Jumlah rimpang yang tumbuh tunas
b. Jumlah tunas
c. Tinggi tanaman
d. Berat basah tanaman

\section{Analisis Data}

a. Daya Bertunas (DB)

$$
\mathrm{DB}(\%)=\frac{\text { Jumlah rimpang yang bertunas }}{\text { Jumlah rimpang yang ditanam }}
$$

b. Indeks Vigor (IV)

IV $(\%)=\frac{\text { Jumlah rimpang yang tumbuh pada hit ke-1 }}{\text { Jumlah rimpang yang ditanam }} \times 100 \%$

\section{HASIL DAN PEMBAHASAN}

\section{A. Kualitas Rimpang}

Persentase hasil kualitas rimpang dapat dilihat pada Tabel 1. 
Tabel 1. Persentase Kualitas Rimpang

\begin{tabular}{lcc}
\hline \multicolumn{1}{c}{ Perlakuan } & DB $(\boldsymbol{\%})$ & IV $(\boldsymbol{\%})$ \\
\hline Kontrol & 100 & 100 \\
15 Menit & 100 & 20 \\
30 Menit & 100 & 40 \\
45 Menit & 100 & 40 \\
60 Menit & 100 & 20 \\
\hline
\end{tabular}

Dari Tabel 1 memperlihatkan bahwa daya bertunas (DB) pada seluruh perlakuan rimpang tanaman kencur mendapatkan hasil yang baik dengan ditunjukkan bahwasannya rimpang berkecambah $100 \%$. Sedangkan pada indeks vigor (IV) mendapatkan hasil yang terbaik pada perlakuan kontrol, kemudian diikuti 30 menit perendaman, kemudian 45 menit perendaman, 15 menit perendaman dan 60 menit perendaman

\section{B. Daya Bertunas (DB)}

Dari Tabel 1. dapat dilihat bahwa seluruh rimpang yang di tanam pada setiap perlakuan mendapatkan hasil yang baik yaitu $100 \%$. Hal ini menunjukkan bahwa seluruh rimpang yang digunakan sebagai benih memiliki cadangan makanan yang cukup sehingga dapat mendukung tunas pada saat perkecambahan dan rimpang tidak terserang penyakit sehingga tunas dapat muncul dengan baik. Menurut Abdillah $d k k$ (2015), bobot rimpang yang cukup memiliki cadangan makanan yang banyak. Cadangan makanan yang lebih banyak akan mendukung tunas muncul pada saat perkecambahan. Rimpang yang mengalami mutu fisik seperti terkena penyakit, kehilangan kandungan air dapat menurunkan daya berkecambah. Menurut BSN (2006) dalam Rusmin $d k k$ (2016), persyaratan rimpang benih yang digunakan sebagai acuan bermutu telah ditetapkan dalam SNI benih jahe pada tahun 2006 sebagai standar mutu rimpang benih jahe putih besar yaitu memiliki daya berkecambah sebesar $\geq$ $80 \%$.

\section{Indeks Vigor (IV)}

Dari Tabel 1. dapat dilihat bahwa persentase indeks vigor yang terbaik terdapat pada perlakuan kontrol dengan nilai $100 \%$. Menurut Kosalanka dkk (2000) dalam Febriani dkk (2015), persentase kecambah normal pada awal pengamatan berhubungan erat dengan kemampuan benih berkecambah di lapang dibandingkan dengan persentase kecambah pada akhir pengamatan.

Hal ini disebabkan adanya kandungan asam absisat pada PGPR sehingga pada rimpang yang diberi perlakuan perendaman dengan larutan PGPR memiliki persentase IV yang rendah dibandingkan dengan kontrol. Menurut Aryantha $d k k$ (2004); Glick dan Penrose (2004); Ana $d k k$ (2011) dalam Rahni (2012), bakteri-bakteri tersebut dapat memproduksi fitohormon yaitu auksin, sitokinin, giberelin, etilen dan asam absisat.

Asam absisat merupakan suatu zat yang dapat menghambat perkecambahan. Adanya asam absisat yang dihasilkan oleh PGPR dapat menghambat pertumbuhan tunas. Menurut Bewley dan Black (1982) dalam Purwaningsih (2001), asam absisat dapat menghambat sintesis asam nukleat dan protein sehingga akan berpengaruh terhadap perkecambahan. Menurut Ranjan dan Lewak (1994) dalam Purwaningsih (2001), asam absisat juga dapat menghambat aktivitas amylase dan aktivitas lipase.

\section{Pertumbuhan Vegetatif}

Berdasarkan percobaan yang telah dilakukan pada rimpang tanaman kencur dengan perlakuan lama perendaman rimpang dengan larutan PGPR, hasil pertumbuhan tanaman kencur pada umur 5 minggu setelah tanam dapat dilihat pada tabel 2 .

Tabel 2. Rata-rata Pertumbuhan Tanaman Kencur Umur 5 Minggu setelah Tanam

\begin{tabular}{lcccc}
\hline Perlakuan & $\begin{array}{c}\text { Jumlah } \\
\text { Rimpang } \\
\text { Tumbuh }\end{array}$ & $\begin{array}{c}\text { Jumlah } \\
\text { Tunas } \\
\text { (buah) }\end{array}$ & $\begin{array}{c}\text { Tinggi } \\
\text { Tanaman } \\
(\mathbf{c m})\end{array}$ & $\begin{array}{c}\text { Berat } \\
\text { Basah } \\
\text { Rimpang } \\
(\mathbf{g})\end{array}$ \\
\hline Kontrol & 5 & 1,2 & 1,22 & 5,02 \\
15 Menit & 5 & 1,4 & 0,42 & 4,88 \\
30 Menit & 5 & 1,4 & 1,26 & 5,02 \\
45 Menit & 5 & 1,8 & 1,74 & 5,9 \\
60 Menit & 5 & 1,2 & 0,8 & 5 \\
\hline
\end{tabular}

\section{Jumlah Rimpang yang Tumbuh Tunas}

Berdasarkan Tabel 2 menunjukkan bahwa pembibitan tanaman kencur dengan rimpang mendapatkan pertumbuhan pada seluruh perlakuan dan sampel rimpang pada minggu ke 5 . Jumlah rimpang yang tumbuh tunas pada setiap pengamatan dari $1 \mathrm{mst}$ hingga $5 \mathrm{mst}$ dapat dilihat pada Gambar 2.

Perbanyakan tanaman kencur dengan menanam rimpang merupakan salah satu perbanyakan yang banyak digunakan. Hal ini 
disebabkan karena tanaman kencur sangat mudah tumbuh dan mudah beradaptasi dengan lingkungan tanam sehingga dapat mudah tumbuh. Rimpang tanaman kencur yang hidup dapat dilihat dari munculnya tunas dan rimpang masih dalam kondisi sehat seperti tidak terserang penyakit. Perbanyakan melalui rimpang didapatkan hasil yang baik dikarenakan pemilihan benih yang sesuai kriteria. Rimpang kencur yang dijadikan benih dengan kriteria kulit berkilat, tekstur daging agak keras, berasal dari pertanaman sehat, dan bebas hama dan penyakit dan tidak cacat. Rimpang yang dijadikan benih memiliki ciri-ciri yang baik yaitu memiliki bobot 5-10 g dan mempunyai 2-3 bakal mata tunas yang baik (Rostiana dan Effendi, 2007).

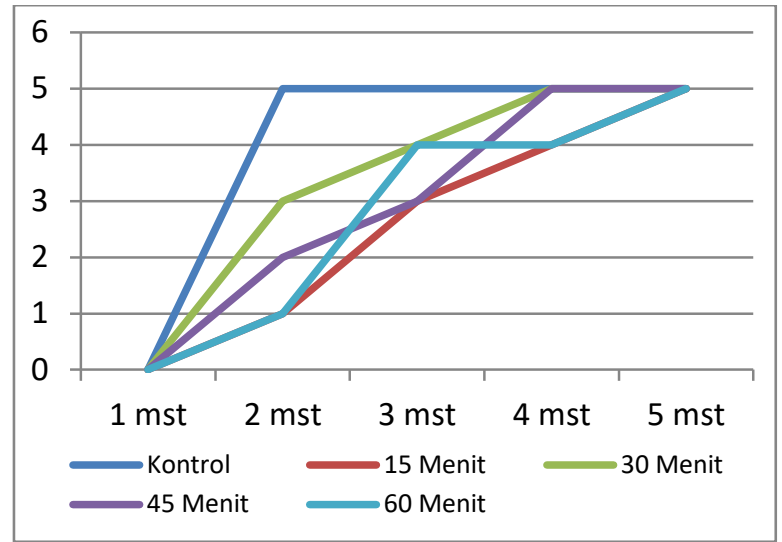

Gambar 2. Grafik Jumlah Rimpang yang Tumbuh Tunas Pada 1 Hingga 5 Minggu Setelah Tanam

\section{Tinggi Tanaman}

Pada Tabel 2 di atas dapat dilihat bahwa perlakuan lama perendaman rimpang tanaman kencur dengan larutan PGPR yang terbaik terdapat pada perendaman 45 menit. Hal ini menunjukkan bahwa dengan dilakukannya perendaman pada rimpang tanaman kencur cukup berpengaruh terhadap pertumbuhan tanaman kencur. Dengan adanya perendaman rimpang dengan larutan PGPR dengan waktu 45 menit maka didapatkan bahwasannya bakteri-bakteri telah ada pada rimpang. Laju pertumbuhan tinggi tanaman kencur dari hasil pengamatan 1 minggu setelah tanam hingga 5 minggu setelah tanam dapat dilihat pada gambar 3.

Berdasarkan gambar 3. Rata-rata laju pertumbuhan tinggi tanaman dengan perlakuan perendaman rimpang kencur dengan larutan PGPR dengan waktu 45 menit memberikan hasil yang terbaik. Sehingga dapat meningkatkan laju pertumbuhan pada tanaman kencur. PGPR memiliki sifat sebagai zat pemacu tumbuh alami yang dapat memacu pertumbuhan tanaman. PGPR yang telah melekat dan hidup pada rimpang tanaman kencur dapat menyebar ke lingkungan sekitar tempat tanam sehingga dapat hidup pada tanah di sekitar tempat penanaman.

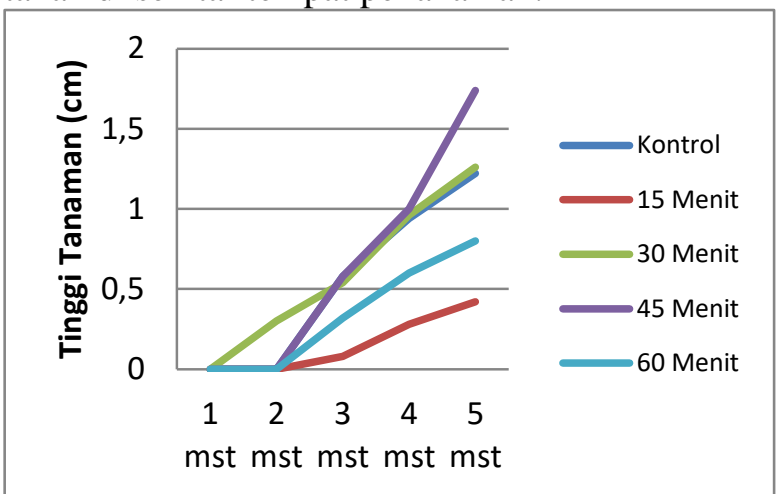

Gambar 3. Grafik Laju Pertumbuhan Tinggi Tanaman Kencur 1 Hingga 5 Minggu Setelah Tanam

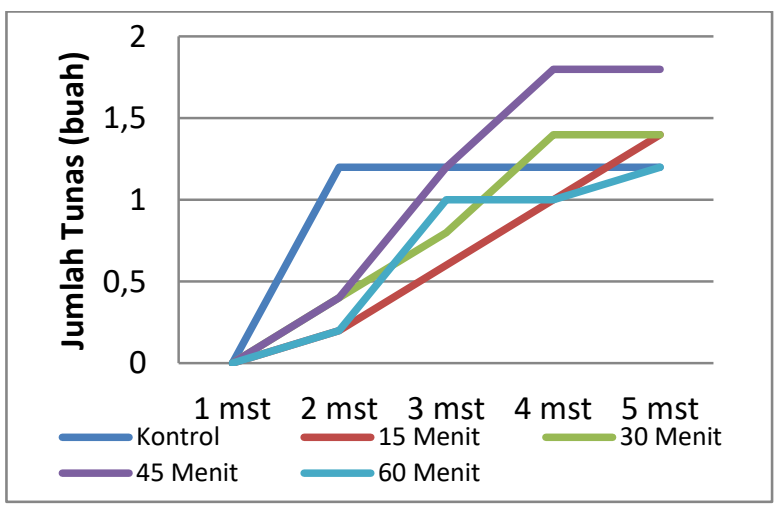

Gambar 4. Grafik Perkembangan Jumlah Tunas Tanaman Kencur pada 1 Minggu Hingga 5 Minggu Setelah Tanam

Menurut Zahir, et al (2004), PGPR yang terdapat di lingkungan tanah dapat menyebabkan perubahan dramatis pada pertumbuhan tanaman melalui produksi zat pengatur tumbuh dan perbaikan nutrisi tanaman dengan menyediakan dan memfalisitasi serapan hara dari tanah. Rimpang kencur juga dapat tumbuh dengan baik dikarenakan rimpang tidak terserang penyakit. Menurut Hermawan (2011), PGPR mampu mengurangi penyakit dan kerusakan pada tanaman serta mampu mempercepat perombakan bahan organik. 


\section{Jumlah Tunas}

Perlakuan perendaman rimpang tanaman kencur dengan larutan PGPR selama 45 menit memberikan hasil terbaik terhadap jumlah tunas pada rimpang tanaman kencur. Jumlah tunas pada rimpang dengan perlakuan perendaman selama 45 menit memiliki rata-rata 1,8 pada pengamatan minggu terakhir. Perkembangan jumlah tunas tanaman kencur dari 1 minggu setelah tanam hingga 5 minggu setelah tanam.

Jumlah tunas pada perlakuan 45 menit lebih baik daripada kontrol karena adanya bakteribakteri yang telah berkembang pada rimpang dan lingkungan tempat tanam. PGPR dapat memproduksi hormon IAA atau auksin. Auksin berperan dalam merangsang pertumbuhan sel, sehingga dapat mempercepat munculnya tunas. Menurut Khalami dan Wirya (2009), penggunaan PGPR dalam meningkatkan pertumbuhan tanaman sangatlah baik. PGPR mampu menghasilkan atau mengubah konsentrasi fitohormon asam indolasetat (IAA), asam giberalat, sitokinin, dan etilen atau prekursirnya (I-aminosiklopropena; ACC diaminase) di dalam tanaman. Menurut Mutyarny $d k k$, (2014), penggunaan zat pengatur tumbuh seperti auksin yang terdapat dalam PGPR dapat merangsang pertumbuhan akar dan munculnya tunas.

Rimpang dengan jumlah tunas yang tinggi akan menghasilkan produksi yang baik dikarenakan pertumbuhan mata tunas akan menghasilkan anakan yang baik. Menurut Buntoro $d k k$ (2014), pertumbuhan tunas erat kaitannya dengan jumlah anakan. Anakan akan menghasilkan umbi sendiri tetapi pada awal pertumbuhannya akan menggunakan cadangan makanan dari umbi yang lama.

\section{Berat Basah Tanaman}

Berdasarkan Tabel 2. perlakuan perendaman rimpang tanaman kencur dengan larutan Plant Growth Promoting Rizobacteria (PGPR) selama 45 menit mendapatkan hasil ratarata berat rimpang dengan berat tertinggi yaitu 5,9 gram.

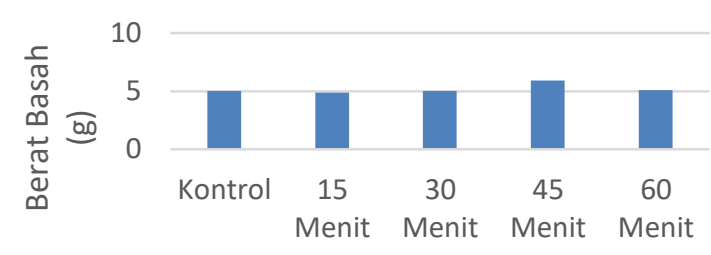

$\begin{array}{ll}\text { Gambar 5. Grafik Perbedaan } & \text { Rata-Rata } \\ \text { Berat Basah Rimpang } & \end{array}$
Hal ini menunjukkan bahwasannya pemberian PGPR terhadap rimpang dengan waktu yang sesuai dapat meningkatkan pertumbuhan tanaman dan dapat membantu penyerapan unsur hara yang ada di tanah. Berat basah rimpang merupakan berat keseluruhan dari bibit tanaman kencur. Meningkatnya bobot tanaman dikarenakan pertumbuhan tanaman yang baik. Menurut Saharan dan Nehra (2011), pemberian PGPR pada tanaman dapat menggantikan pupuk kimia, pestisida, dan hormon yang dapat digunakan dalam pertumbuhan tanaman sehingga PGPR dapat meningkatkan tinggi tanaman dan berat tanaman.

\section{KESIMPULAN}

1. Pemberian Plant Growth Promoting Rizhobacteria (PGPR) pada perendaman rimpang tanaman kencur berpengaruh terhadap pertumbuhan bibit tanaman kencur.

2. Perlakuan perendaman rimpang tanaman kencur dengan larutan PGPR pada lama perendaman 45 menit memiliki hasil yang terbaik.

\section{DAFTAR PUSTAKA}

Abdillah, R.H., Rogomulyo, R dan Purwanti, S. 2015. Pengaruh Bobot Rimpang dan Tempat Penyimpanan terhadap Mutu Bibit Rimpang Jahe (Zingiber officinale Rosc). Vegetalika. 4(4) : 57-67.

Afriastini, J. J. 2002. Bertanam Kencur. Penebar Swadaya. Jakarta.

Ardiyanto, F. M, Karyawati, A. S dan Sitompul S. M. 2017. Pengaruh Frekuensi Pemberian dan Konsentrasi Rizhobakteri Pemacu Pertumbuhan Tanaman terhadap Pertumbuhan dan Hasil Kedelai Sayur (Glycine max L. Merrill). Jurnal Produksi Tanaman. 5(11) : 1762-1767.

Arfandi. 2019. Pengaruh Beberapa Plant Growth Promoting Rizhobacteria (PGPR) terhadap Pertumbuhan dan Produksi Tanaman Kedelai (Glycine max L. Merill). Fakultas Pertanian, Universitas Muslim Maros, Maros.

Buntoro, B.H., Rugomulyo, R dan Trisnowati, S. 2014. Pengaruh Takaran Pupuk Kandang dan Intensitas Cahaya terhadap Pertumbuhan dan Hasil Temu Putih 
(Curcuma zedoria L.). Vegetalika. 3(4) : 29-39.

Febriani, L.Y dan Widajati, E. 2015. Evaluasi Beberapa Tolak Ukur Vigor untuk Pendugaan Perpanjangan Masa Edar Benih Padi (Oryza sativa L.).. Bul. Agrohorti. 3(3) : 309-315.

Firmansyah, A., Markum dan Indriyanto. 2018. Pengaruh Komposisi Media Tanam dan Pemberian Dosis Pupuk PGPR (Plant Growth Promoting Rizhobacteria) terhadap Pertumbuhan Semai Ketimun (Gyrinops versteegil). Program Studi Kehutanan. Universitas Mataram. Jurnal Belantara. 1(1) : 30-34.

Hermawan, Y. 2011. Pengaruh Beberapa Media Tanam terhadap Pertumbuhan Cabai Keriting (Capsicum annum L.) Varietas CA-237. Fakultas Pertanian, Universitas Cianjur, Cianjur. Skripsi.

Khalimi, K dan Wirya. 2009. Pemanfaatan Plant Growt Promoting Rizhobacteria untuk Biostimulatns dan Bioprotectans. Jurnal Ecotrophic. 4(2): 131-135.

Kii, K. K. 2018. Pengaruh Sari Rimpang Kencur (Kaempferia galangal L.) terhadap Sifat Organoleptik pada Pembuatan Yoghurt Susu Kambing. Universitas Sanata Dharma, Yogyakarta. Skripsi.

Lestari, E. G. 2011. Peranan Zat Pengatur Tumbuh dalam Perbanyakan Tanaman melalui Kultur Jaringan. Balai Besar Penelitian dan Pengembangan Bioteknologi dan Sumberdaya Genetik Pertanian. Bogor.

Mutyarny, E., Endriyani dan Lestari, S.U. 2014. Pemanfaatan Urine Kelinci untuk Meningkatkan Pertumbuhan dan Produksi Tanaman Sawi (Brassica juncea L.) Varietas Tosakan. Jurnal Ilmiah Pertanian. 11(2) 23-34.

Pramudyo, A. 2018. Budi Daya dan Bisnis Jahe, Lengkuas, Kunyit, dan Kencur. PT AgroMedia Pustaka. Jakarta.

Purwaningsih, O. 2001. Kajian Fisiologis dan Biokimia Benih Rambutan (Nephelium lappaceum L.) Selama Penyimpanan dengan Perlakuan ABA dan $\mathrm{GA}_{3}$. Ilmu Penelitian. 8(2) 66-75.

Rahni, N.M. 2012. Efek Fitohormon PGPR terhadap Pertumbuhan Tanaman Jagung (Zea mays). Jurnal Agribisnis dan Pengembangan Wilayah. 3(2) 27-35.
Rusmin, D., Sukarmin dan Wahyudi, A. 2016. Teknologi Produksi dan Pengawasan Mutu Rimpang Benih Jahe Putih Besar (Zingiber officinale Rosc). Balai Penelitian Tanaman Rempah dan Obat. Pusat Penelitian dan Pengembangan Perkebunan. Bogor

Rostiana, O dan Effendi, D.S. 2007. Teknologi Unggulan Kencur. Pusat Penelitian dan Pengembangan Perkebunan. Bogor.

Saharan, B. S dan Nehra, V. 2011. Plant Growth Promoting Rizhobacteria. Jurnal Produksi Tanaman. 5(3) : 473-380.

Samanhudi., Rahayu, M., Pujiasmanto, B., Yunus, A dan Rahmawati, D. 2016. Respon Pertumbuhan Kencur (Kaemprefia galanga L.) terhadap Pemberian IBA dan BAP secara In Vitro. Biota. 1(1) : 26-30.

Sulistyoningtyas, M. E., Roviq, M dan Wardiyati, T. 2017. Pengaruh Pemberian PGPR (Plant Growth Promoting Rizhobacteria) pada Pertumbuhan Bud Chip Tebu (Saccharum officinarum L.). Jurnal Produksi Tanaman. 5(3) : 396-403.

Utami, A. P., Agustiyani, D dan Handayanto, E. 2018. Pengaruh PGPR (Plant Growth Promoting Rizhobacteria), Kapur, dan Kompos pada Tanaman Kedelai di Ultisol Cibinong, Bogor. Jurnal Tanah dan Sumberdaya Lahan. 5(1) : 629-635.

Widawati, S. 2015. Isolasi dan Aktivitas Plant Growth Promoting Rizhobacteria (Rizhobium, Azospirillum, Azotobacter, Pseudomonas) dari Tanah Perkebunan Karet, Lampung. Berita Biologi. 14(1) : 77-88.

Zahir, Z. A., Khalid, A dan Arshad, M. 2004. Screening Plant Growth Promoting Rizhobacteria for Improving Growth and Yield of Wheat. J.Appl. Microbiol. 96: 473-380 